\section{THE TEXTILE INSTITUTE}

\author{
By Prof. W. E. MORTON \\ College of Technology, Manchester
}

$I^{N}$ 1910 the Textile Institute, the professional body of textile technologists, was founded "to advance the general interests of the textile industry, more particularly in relation to the acquisition and application thereto of scientific knowledge". On April 4, 1952, its new headquarters at 10 Blackfriars Street, Manchester, were officially opened by the president, Mr. G. H. Spencer, at a ceremonial unveiling of a tablet commemorating the names of the fifteen founding members.

The necessity for new and more commodious premises has arisen mainly because of the remarkable post-war growth of the Institute's membership and activities. In its early days it developed slowly : when it received its Royal Charter in 1925 its membership was just over 1,000, and by 1939 this number had increased to 1,700 . But since 1946 no less than 4,637 new members have joined, and the current membership of more than 5,600 is still growing at the rate of a hundred or so a month.

This rapid expansion is in part due to the growing recognition that industries in general, and the traditional industries in particular, depend very largely for their future prosperity on a more widespread application of science and the scientific method of approach to the problems of their materials, processes and organization. But it is also due to the part which the Institute itself has played in developing this climate of opinion, and to the high esteem in which its Journal and its diplomas have come to be held by textile technologists throughout the world. It is not, and never has been, a purely national bodya fact which is symbolized in the crest of its arms. More than a thousand of its members, including 271 fellows and associates, are drawn from overseas, and in recent years its examinations for the award of diplomas have been held at centres in seventeen foreign countries. The Journal, which is the official organ of publication for the several textile research associations, is universally acknowledged to be without equal in the textile field, both for the quality of the papers contributed and for its abstracts of current textile literature, which are immeasurably more comprehensive than anything of the kind published elsewhere.

Besides setting up high standards of technical literature through its Journal, and of professional competence through the award of diplomas, the Institute serves the purposes laid down in its charter in many other ways : by the award of scholarships and prizes; by the unification of testing methods; by the codification of textile terminology; and by the organization of conferences and lectures. In the conduct of its affairs, the Council is assisted by fourteen standing committees with their numerous subcommittees and overseas advisory panels; and as the membership has grown so also have the demands upon the Institute's resources - in offices for the expanding staff and meeting rooms for the greatly increased amount of committeo work that has to be done.

Since the Second World War, the old premises in St. Mary's Parsonage, considered even in 1925 to be "none too commodious", have been quite inadequate for their purpose, and administration has had to be carried on under increasingly difficult conditions. Staff had to be accommodated wherever there was space, and serious inroads were made into such limited accommodation as had previously been available for members. In its new headquarters, the Institute now has offices which not only satisfy its administrative requirements but also make possible the restoration and augmentation of the general facilities for its members. Particularly appreciated among these are the lecture theatre to seat 165 in comfort, the handsomely furnished members' room, the dining-room, and the adequate housing of the Institute's extensive library.

The opening ceremony was performed at a convocation for the award of medals and diplomas, following which the assembly was addressed by Dr. Percy Dunsheath on the subject of "Education, Technology and Management". Dr. Dunsheath's theme was the relatively low esteem in which technological studies are held in Great Britain as compared with the United States and elsewhere. Though the situation is improving, he said, there are still far too many in a position to influence the careers of young men who are apt to look down on any sort of education that is directed to a useful end. This, he contended, is a state of affairs that must be rectified, and quickly, if Britain is to maintain itself in the forefront of industrial nations. Technological education, based as it must be on a sound foundation of fundamental science, has every right to claim a status on a par with that of any other form of academic study; and unless it is accorded that recognition, industry would fail to attract its due share of the best brains in Britain, by which alone it can survive in the face of modern world competition.

\section{EDUCATION GROUP OF THE INSTITUTE OF PHYSICS}

\section{ANNUAL CONFERENCE}

SCHOOL and university examinations in physics $S$ were discussed at the annual conference of the Education Group of the Institute of Physics, held at the Institute's House during April 17-19. The opening paper by Mr. J. L. Brereton (general secretary, Cambridge University Local Examinations Syndicate) on "The Place of Examinations in Education", explained the aims of a school examination. It is the modern equivalent of the master's criticism of his apprentice. The external examination goes further, in that it tests teachers as well as pupils, and can exert a profound influence for good on the courses of study in schools. The General Certificate of Education, which can be taken in single subjects and not necessarily from school, does not of itself imply the completion of an approved course; and only by close co-operation between examining bodies and the schools can its value be maintained. $\mathrm{Mr}$. Brereton said he believes that group intelligence tests are similar in nature to conventional examinations, but at a very low level of knowledge. He had experimented with an interchange of papers with American schools, and the results so far suggested a high correlation between marks obtained in the General Certificate papers and in their objective tests. $\mathrm{He}$ believes there must eventually be a move towards the establishment of internal examinations conducted 